\title{
Editorial vol 75(1) March 2022
}

B. N. Chakraborty ${ }^{1,2}$

(c) Indian Phytopathological Society 2022

Dear Reader,

The first issue, volume 75 of Indian Phytopathology for January-March 2022 is ready. In this issue there are thirty five articles including twenty one research articles, eleven short communications and three new reports.

Predisposition by root borer Polyocha depresella is a myth or reality, that has been explained with special reference to epidemiology for sugarcane wilt. Nitric oxide mediated defense responses in common bean against Colletotrichum gloeosporioides infection have been validated. Morphological and molecular characterization of Sclerotium rolfsii associated with stem rot disease of groundnut and biochemical and molecular evaluation of pigeonpea against Fusarium wilt have been documented. Multiple disease resistant tomato lines through marker assisted breeding have been developed and further evaluated for their horticultural traits. Functional analysis of SCD1 gene involved in pathogenicity of spot blotch disease of wheat causing fungus Bipolaris sorokiniana and inheritance and allelic relationship between genes conferring resistance to Pyricularia ory$z a e$ in rice have been demonstrated. Rice genotypes were evaluated in order to identify potential sources for resistance breeding against varying population densities of root-knot nematode-Meloidogyne graminicola. Fruit and seed mycoflora of bottle gourd (Lagenaria siceraria) were isolated and aggressiveness of Fusarium species obtained from different head parts of wheat under in vitro conditions were evaluated. Synthesis of gold nanoparticles and assessment of in vitro toxicity against plant pathogens as well as synthesis, characterization and inhibition effects of Jhingan gum-induced silver nanoparticles against powdery mildew of pea have been described. Eco-friendly management of seed discolouration

B. N. Chakraborty

bncnbu@gmail.com

Indian Phytopathological Society, New Delhi, India

2 Department of Biological Sciences, Aliah University, Kolkata, India of paddy and effectiveness of eight Trichoderma species against Sclerotinia sclerotiorum causing white mould of pea have been reported. Biocontrol potentials of novel indigenous Trichoderma isolates against Fusarium wilt of chickpea and seed biopriming with Trichoderma in ameliorating salinity stress and resistance against leaf blast disease in finger millet have been demonstrated. Characterization and evaluation of extracellular hydrolytic proteins from rhizobacterial antagonists isolated from Fusarium oxysporum $\mathrm{f}$. sp. ciceris infected chickpea fields and biocontrol prospective of Bacillus siamensis-AMU03 against soil-borne fungal pathogens of potato tubers have been discussed. Impact of weather parameters on the development of bacterial leaf spot in bottle gourd and pumpkin have been presented. Molecular analysis of Tomato Yellow Leaf Curl Virus in Iran and molecular characterization of Cucumber mosaic virus subgroup II isolate associated with cucumber in Bangladesh have been discussed.

Development of species-specific PCR based detection assay for Ceratocystis fimbriata, mango wilt pathogen and rapid identification of Corynespora cassiicola by multiplex PCR have been explored. A machine learning-based spray prediction model for tomato powdery mildew disease, pathogenicity of Ceratocystis manginecans in Acacia roots and responsiveness of Albugo candida isolates causing white rust in different crucifers have been described. Choanephora cucurbitarum inciting twig blight of chilli and basis of Karnal bunt resistance in diploid and tetraploid Triticeae species have been elucidated. Genetic diversity of Sclerotium rolfsii have been analysed employing ITS, ISSR and RAPD markers. Management of Sclerotium rolfsii causing basal rot of Piper longum through organic approaches and biocontrol potential of indigenous Trichoderma strains from pulses rhizosphere have been evaluated against Fusarium oxysporum f. sp. ciceri in chickpea. Morphological, symptomatological and molecular characterization of Enterobacter cloacae causing bacterial wilt in African marigold (Tagetes erecta) has been documented.

New records of Canker and Wilt disease in eucalypt caused by Ceratocystis manginecans in Vietnam, Pokkah 
boeng of maize caused by Fusarium luffae and Cactus virus $\mathrm{X}$ in Dragon fruit (Hylocereus spp.) in India have been reported.

Authors, reviewers, editorial board members, executive council members of Indian Phytopathological Society and business manager who have put in lot of efforts to bring out timely publication of this issue are gratefully acknowledged. Authors are requested to submit the best research/review articles to Indian Phytopathology to maintain its quality and high standards.
Prof. B. N. Chakraborty.

Chief Editor, Indian Phytopathology.

Publisher's Note Springer Nature remains neutral with regard to jurisdictional claims in published maps and institutional affiliations. 